\title{
Synthesis, Characterization, and Anti-microbial Study of Polycyclicacetal Metal Complexes Derived from PEG and (Erythro-Ascorbic Acid) Derivative
}

\author{
Maha A. Younus, Bassam I. Khalil, Taha M. Salih, and Rasmia M. Rumez
}

\begin{abstract}
Polymer metal complexes of poly ethylene glycol acetal and $\mathrm{Ag}$ (I), Cu (II), Ni (II), Mn (II), Co (III) and Hg (II) were prepared from the reaction of PEG with aldehyde derived fromErythro-ascorbic acid (pentulosono-y-lactone-2, 3enedianisoate). All these compounds were characterized by Thin Layer Chromatography (TLC) and FTIR spectra and aldehyde was also characterized by (U.V-Vis), ${ }^{1}$ HNMR, ${ }^{13}$ CNMR, and mass spectra. It has been established that, the polymer and its metal complexes showedgood activities against four pathogenic bacteria (Escherichia coli, Klebsiellapneumonae,Staphylococcusaureus, Staphylococcus Albus) and two fungal (Aspergillus Niger,Yeast). The polymer metal complexes showed higher activity than the free polymer.Theorder of increasing activities was polymer $<$ polMn $<$ pol-Ni $<$ pol-Co $<$ pol-Cu $<$ pol-Hg $<$ pol-Ag. The ability of these compounds to show antimicrobial and antifungal properties suggests that, they can be further evaluated for medicinal and/or environmental applications.
\end{abstract}

Index Terms-Antimicrobial activity, PEG, polycyclicacetal, polymer metal complexes.

\section{INTRODUCTION}

Microbial infection remains one of the most serious complications in several areas, particularly in medical devices, drugs, health care and hygienic applications, water purification systems, hospital and dental surgery equipment, textiles, food packaging, and food storage. Antimicrobials gain interest from both academic research and industry due to their potential to provide quality and safety benefits to many materials. However, low molecular weight antimicrobial agents suffer from many disadvantages, such as toxicity to the environment and short-term antimicrobial ability. To overcome problems associated with the low molecular weight antimicrobial agents, antimicrobial functional groups can be introduced into polymer molecules. The use of antimicrobial polymers offers promise for enhancing the efficacy of some existing antimicrobial agents and minimizing the environmental problems accompanying conventional antimicrobial agents by reducing the residual toxicity of the agents, increasing their efficiency and

Manuscript received April 2, 2015; revised June 18, 2015

Maha A. Younus and Rasmia M. Rumez are with the Department of Chemistry, College of Eduation-Ibn-Haitham, University of Baghdad, Iraq (e-mail: ma2004ha@yahoo.com, maha_abaychi@yahoo.com)

Bassam I. Khalil was with the Department of Materials Engineering, Branch of Polymer Materials Engeering, College of Engineering, University of Technology, Baghdad, Iraq.

Taha M. Salih was with the Department of Science, College of Basic Education, University of Al-Mustenseryah, Iraq. selectivity, and prolonging the lifetime of the antimicrobial agents [1].

In recent years, more interests have been emphasized in the synthesis of polymers containing polyacetal segments, because of the ease of degradation of these polymers under mild conditions by treatment with a trace of acid [2].

Polyethylene glycol (PEG) is finding a rapidly expanding use in biochemical and bio medical applications. It has been found to be non-toxic, non-immunogenic and water soluble. PEG has therefore been used in protein modification to decrease antigenicity, prolong its plasma circulatory half-life and to increase its solubility and thermal stability [3]-[6].

L-ascorbic acid (LAA; i.e., vitamin C, a water soluble vitamin) contains a variety of biological, pharmaceutical and dermatological functions; for example, it can promote collagen biosynthesis, provide photoprotection, scavenge free radical, cause melaninreduction and enhances the immunity (e.g., anti-viral effect) [7]-[9]. From the perspective in biochemistry, these functions are closely related to the so-calledantioxidant properties of this compound.

\section{EXPERIMENTAL}

\section{A. Preparation of Polycyclicacetal}

Melting points were determined by electrothermal Stuart melting point apparatus and are uncorrected.IR spectra (in $\mathrm{KBr}$ ) were recorded on 8400s Shimadzu FT infrared spectrophotometer. ${ }^{1} \mathrm{HNMR}$ spectrum was recorded on Ultra Shield (300 MHz) spectrometer with tetramethylsilane as internal standard. ${ }^{13} \mathrm{CNMR}$ spectrumwas recorded on a Varian Mercury plus $100 \mathrm{MHz}$ spectrometer. Electronic spectrum was obtained using a (U.V-Vis) spectrophotometer type CECl 7200 England. Mass spectrum was recorded on IEOLJMS-7high resolution instrument. Thin layer chromatography (TLC) was performed on aluminum plates coated with layer of silica gel, supplied by Merck. The spots were detected by iodine vapor. All chemical were obtained from Fluka or BDH.

\section{B. Synthesis of 5, 6-O-Isopropylidene-L-Ascorbic Acid (2)}

Dry hydrogen chloride was rapidly bubbled with stirring for 20 minutes into a $(250 \mathrm{ml})$ flask containing $(10 \mathrm{~g}$, $57 \mathrm{mmol}$ ) of powdered L-ascorbic acid (1) and (100ml) of dry acetone.

After addition of $(80 \mathrm{ml}) \mathrm{n}$-hexane, stirring and cooling in an ice-water, the supernatant was decanted. The precipitate was washed four times with $(154 \mathrm{ml})$ ofacetone-hexane mixture (4:7) $(\mathrm{v} / \mathrm{v})$, cooling in an ice-water and removal of 
supernatant after each addition. The last precipitate was dried under reduced pressure to give (2) $(95.35 \%)$ as a white crystalline residue [10], m.p $\left(206-208^{\circ} \mathrm{C}\right) . \quad \mathrm{R}_{\mathrm{f}}(0.68)$ (benzene: methanol, 5:5) (v/v). FTIR $\left(\mathrm{KBr}, \mathrm{cm}^{-1}\right): 3240(\mathrm{O}-$ $\mathrm{H}), 2993\left(\mathrm{C}-\mathrm{H}_{\text {ali. }}\right), 2908\left(\mathrm{C}-\mathrm{H}_{\text {ace. }}\right), 1751\left(\mathrm{C}=\mathrm{O}_{\text {lac. }}\right), 1662$ $(\mathrm{C}=\mathrm{C}), 1431\left(-\mathrm{CH}_{-}{ }_{\text {asym }}\right), 1388\left(-\mathrm{CH}_{-}{ }_{\text {sym }}\right), 1141-900(\mathrm{C}-\mathrm{O})$, $767 \delta(\mathrm{O}-\mathrm{H})$ (O.O.P.) [11].

\section{Synthesis of 2,3-O-Dianisoyl-5,6-O-Isopropylidene-L- Ascorbic Acid (3)}

To a cold solution of (2) $(10 \mathrm{~g}, 46 \mathrm{mmol})$ in pyridine $(50 \mathrm{ml})$, anisoyl chloride was added as dropwise $(17.5 \mathrm{ml}$, $129 \mathrm{mmol}$ ) with stirring. The resulting mixture was stirred for 2 hours, then kept in dark place at room temperature for 22 hours.

The mixture was poured into ice-water and stirred for 20 minutes, the supernatant was decanted. The oil layer was extracted with chloroform $(150 \mathrm{ml})$, washed with water, dilute hydrochloric acid $(5 \%)(2 \times 100 \mathrm{ml})$, saturated aqueous sodium hydrogen carbonate $(100 \mathrm{ml})$ and water. Dried over anhydrous magnesium sulfate, Chloroform was evaporated to produce a brown syrup and purified from chloroform: petroleum ether $\left(60-80^{\circ} \mathrm{C}\right)(1: 5)(\mathrm{v} / \mathrm{v})$ to give $(3)(76.5 \%)$ as a pale yellow solid [12]-[14], m.p $\left(102-104^{\circ} \mathrm{C}\right) . \mathrm{R}_{\mathrm{f}}(0.80)$ (benzene: methanol, 5:5) (v/v). FTIR $\left(\mathrm{KBr}, \mathrm{cm}^{-1}\right): 3028(\mathrm{C}-$ $\left.\mathrm{H}_{\text {ar. }}\right), 2983\left(\mathrm{C}-\mathrm{H}_{\text {ali. }}\right), 2939\left(\mathrm{C}-\mathrm{H}_{\text {ace. }}\right), 2843\left(\mathrm{OC}-\mathrm{H}_{\text {ali. }}\right), 1749$ $\left(\mathrm{C}=\mathrm{O}_{\text {lac. }}\right), 1683\left(\mathrm{C}=\mathrm{O}_{\text {est. }}\right), 1647\left(\mathrm{C}=\mathrm{C}_{\text {ali. }}\right), 1604 \quad\left(\mathrm{C}=\mathrm{C}_{\text {ar. }}\right)$, 1300-1107 (C-O est. $), 900-600 \delta(\mathrm{C}-\mathrm{H})$ (O.O.P.).

\section{Synthesis of 2,3-O-Dianisoyl-L-Ascorbic Acid (4)}

Compound (3) $(10 \mathrm{~g}, 23.6 \mathrm{mmol})$ was dissolved in mixture $(65 \%)$ acetic acid $(30 \mathrm{ml})$ and absolute methanol $(10 \mathrm{ml})$ and stirred for 48 hours at room temperature. The TLC showed that the reaction was complete (benzene: methanol, 6:4).

To the resulting solution benzene $(40 \mathrm{ml})$ was added and evaporated (repeat this process four times) [12]-[14].The residue recrystallized from chloroform and then diethyl ether to yield (4) $(77.7 \%)$ as a white crystals, m.p (130$\left.132^{\circ} \mathrm{C}\right), \mathrm{R}_{\mathrm{f}}(0.42)$. FTIR $\left(\mathrm{KBr}, \mathrm{cm}^{-1}\right): 3444(\mathrm{O}-\mathrm{H}), 3008(\mathrm{C}-$ $\left.\mathrm{H}_{\text {ar. }}\right), 2972\left(\mathrm{C}-\mathrm{H}_{\text {ali. }}\right), 2843\left(\mathrm{OC}-\mathrm{H}_{\text {ali. }}\right), 1741\left(\mathrm{C}=\mathrm{O}_{\text {lac. }}\right), 1681$ $\left(\mathrm{C}=\mathrm{O}_{\text {est }}\right), 1647 \quad\left(\mathrm{C}=\mathrm{C}_{\mathrm{ali}}\right), 1606\left(\mathrm{C}=\mathrm{C}_{\mathrm{ar} .}\right),(1319-1112)(\mathrm{C}-$ $\left.\mathrm{O}_{\text {est. }}\right), 900-600 \delta\left(\mathrm{C}-\mathrm{H}_{\text {ar. }}\right)($ O.O.P. $)$ [12]-[14].

\section{E. Synthesis of Pentulosono- $\gamma$-Lactone-2, 3-Enedianisoate} (5)

To the stirred solution of sodium periodate $(5.6 \mathrm{~g}, 26 \mathrm{mmol})$ in distilled water $(60 \mathrm{ml})$ at $\left(0^{\circ} \mathrm{C}\right)$, a solution of $(4)(10 \mathrm{~g}$, $26 \mathrm{mmol})$ in absolute ethanol $(60 \mathrm{ml})$ was added drop wise. After stirring for 15 minutes, ethylene glycol $(0.5 \mathrm{ml})$ was added as dropwise, stirring was continued at room temperature for 1 hour [12]-[14].

The mixture was filtered and to the filtrate water $(40 \mathrm{ml})$ was added then the product was extracted with ethyl acetate $(3 \times 50 \mathrm{ml})$, the extracts dried by anhydrous magnesium sulfate, then filtered and the solvent was evaporated and the residue recrystallized from benzene to yield the pure product of compound (5) (45\%) as a white crystals, m.p (156-158 $\left.{ }^{\circ} \mathrm{C}\right)$. $\mathrm{R}_{\mathrm{f}}(0.70)$ (benzene: methanol, 6:4) (v/v). FTIR $\left(\mathrm{KBr}, \mathrm{cm}^{-1}\right)$ : $3040\left(\mathrm{C}-\mathrm{H}_{\mathrm{ar}}\right), 2983\left(\mathrm{C}-\mathrm{H}_{\text {ali. }}\right), 2843\left(\mathrm{OC}-\mathrm{H}_{\text {ali. }}\right),(2671,2559)$ $\left(\mathrm{C}-\mathrm{H}_{\text {ald. }}\right), 1782\left(\mathrm{C}=\mathrm{O}_{\text {lac. }}\right), 1749\left(\mathrm{C}=\mathrm{O}_{\text {ald. }}\right), 1685\left(\mathrm{C}=\mathrm{O}_{\text {est. }}\right)$, $1604\left(\mathrm{C}=\mathrm{C}_{\mathrm{ar}}\right), \quad 1300-1107 \quad\left(\mathrm{C}-\mathrm{O}_{\mathrm{est}}\right), \quad 900-600 \quad \delta\left(\mathrm{C}-\mathrm{H}_{\text {ar. }}\right)$ (O.O.P.). ${ }^{1} \mathrm{HNMR}$ (DMSO $\delta \mathrm{ppm}$ ): 12.5 (s, 1H, CHO ), 7.00- $7.97\left(\mathrm{dd}, 8 \mathrm{H}\right.$, aromatic), $3.86\left(\mathrm{~s}, 1 \mathrm{H}, \mathrm{H}_{4}\right), 3.82(\mathrm{~s}, 6 \mathrm{H}$, $\left.2 \mathrm{OCH}_{3}\right)$ [11]. ${ }^{13} \mathrm{CNMR}(\mathrm{DMSO} \delta \mathrm{ppm}): 167.50\left(\mathrm{C}=\mathrm{O}_{\text {lac. }}\right)$, $163.32\left(\mathrm{C}=\mathrm{O}_{\text {est. }}\right), 131.86(\mathrm{C}-4), 131.83(\mathrm{C}-3), 131.81(\mathrm{C}-2)$, $(123.44,114.31,114.28,114.26)\left(\mathrm{C}_{\mathrm{ar} .}\right), 55.90\left(\mathrm{OCH}_{3}\right)$. The signal of aldehydic carbonyl was disappeared due to it showed out of the scale [15]. MS, (positive ion) $\mathrm{m} / \mathrm{z}$ (relative intensity): $413[\mathrm{M}+1,(100)], \mathrm{UV}\left(\lambda_{\max }, \mathrm{nm}, \mathrm{CHCl}_{3}\right)$ : 300 .

\section{F. Synthesis of Polyvinyl Acetal (6)}

Compound (5) was dissolved in a mixture of benzene $(8 \mathrm{ml})$ and ethanol $(2 \mathrm{ml})$ with two drops of HCl. PEG $(\mathrm{Mw}=$ $4000,0.5 \mathrm{~g}$ ) was added to the mixture with vigorous stirring at $(40-50)^{\circ} \mathrm{C}$ for $24 \mathrm{hr}$. The solution was poured into excess amount of methanol $(100 \mathrm{ml})$ containing equimolar amount of $\mathrm{NaOH}$, the product was separated by filtration and then washed with methanol and dried under vacuum. FTIR $\left(\mathrm{KBr}, \mathrm{cm}^{-1}\right): 3448(\mathrm{O}-\mathrm{H}), 3057\left(\mathrm{C}-\mathrm{H}_{\mathrm{ar}}\right), 2954\left(\mathrm{C}-\mathrm{H}_{\mathrm{ali}}\right)$, $1597\left(\mathrm{C}=\mathrm{O}_{\text {anisoate }}\right), 1279-1068\left(-\mathrm{C}-\mathrm{O}-\mathrm{C}_{\mathrm{ac}}\right), 923-680\left(\mathrm{C}-\mathrm{H}_{\mathrm{ar}}\right)$.

\section{G. Preparation of the Polycyclicacetal Metal Complexes}

The Silver nitrate $\left(\mathrm{AgNO}_{3}\right)$ and Mercury chloride $\left(\mathrm{HgCl}_{2}\right)$ were obtained from Fluka. Nickel chloride $\left(\mathrm{NiCl}_{2} \cdot 6 \mathrm{H}_{2} \mathrm{O}\right)$, Manganese Sulfate $\left(\mathrm{MnSO}_{4} \cdot \mathrm{H}_{2} \mathrm{O}\right)$, Cobalt chloride $\left(\mathrm{CoCl}_{2} \cdot \mathrm{H}_{2} \mathrm{O}\right)$ and Copper chloride $\left(\mathrm{CuCl}_{2} \cdot 2 \mathrm{H}_{2} \mathrm{O}\right)$ were obtained from Aldrich.Sabouraud agar, Blood Agar Base,MacConky Agar and Nutrient Broth were obtained from Oxoid LTD.

The general procedure for preparation of metal complex by preparing $5 \%$ from polymer solution and mixed with equal ratios of metal solution $(\mathrm{Cu}, \mathrm{Co}, \mathrm{Ni}, \mathrm{Mn}, \mathrm{Ag}, \mathrm{Hg})$ (10mmol), mixture was stirred for $1 \mathrm{hr}$.

\section{H. Evaluation Testing of Antimicrobial Activity}

Antimicrobial susceptibility test measures the ability of an antimicrobial agent to inhibit or kill bacterial growth in vitro. This ability may be estimated by either the dilution method or the diffusion method. In this work we followed the broth dilution method.Certain bacteria and fungi isolates were chosen, Escherichia-Coli and KlebsiellaPeneumoniae were representing gm-ve isolates, Staphylococcusaureus and Staphylococcus albeus were representing gm+ve isolates, two fungal (Aspergillusniger, Yeast).Those Isolates were taken from about 50 patients at CPHL (Central Public Health Laboratory in Baghdad).

The broth dilution method: Serial twofold dilutions of an antimicrobial agent are incorporated into broth containing tubes that are then inoculated with a standard number of organisms usually $10^{5}-10^{6}$ colony-forming units (CFU) per milliliter. After the culture has been incubated at $37 \mathrm{C}^{0}$ for 18 hr. The lowest concentration that prevents growth after overnight incubation is known as the minimum inhibitory concentration (MIC) of the agent. The MIC is defined as the lowest concentration of antimicrobial agent at which there is no visible growth [16], [17].

\section{RESULTS AND DISCUSSION}

\section{A. Spectroscopic Studies}

In the present work the synthesis of new polyacetal was achieved from pentulosono- $\gamma$-lactone-2, 3-enedianisoate (5), 
scheme (1). The first step employs the protection of the hydroxyl groups at C-5 and C-6 positions in L- ascorbic acid with acetal formation leading to compound (2) using dry acetone in acidic media, following Salomon [10] method. This is followed by esterification of the hydroxyl groups at C-2 and C-3 positions with excess of anisoyl chloride in dry pyridine.for $(\mathrm{O}-\mathrm{H})$ of compound (2) and exhibited the band at $(1683) \mathrm{cm}^{-1}$ for $(\mathrm{C}=\mathrm{O})$ of the ester in compound (3) spectrum.

TABLE I: ANTIBACTERIAL ACTIVITY OF THE POLYACETAL AND ITS METAL COMPLEXES (MINIMUM INHIBITORY CONCENTRATION)

\begin{tabular}{|c|c|c|c|c|c|c|c|c|c|c|c|c|c|c|c|c|c|c|c|c|c|}
\hline \multicolumn{3}{|c|}{ 它录 } & \multicolumn{3}{|c|}{ 方春 } & \multicolumn{3}{|c|}{ 言 } & \multicolumn{3}{|c|}{ 2三 } & \multicolumn{3}{|c|}{ 羷春 } & \multicolumn{3}{|c|}{ 点春 } & \multicolumn{3}{|c|}{ 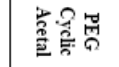 } & 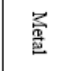 \\
\hline & 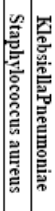 & 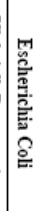 & & 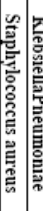 & & & 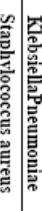 & 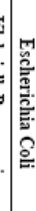 & & 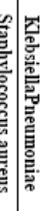 & 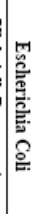 & & 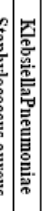 & 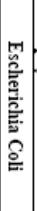 & 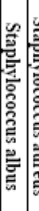 & 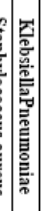 & & 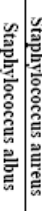 & & & 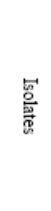 \\
\hline & 苦岸 & 岸 & & $\underset{\vec{\omega}}{\vec{d}}$ & 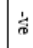 & & 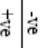 & id & 声 & 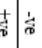 & 岸 & $\frac{3}{a}$ & 感 & 殅 & 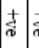 & $\frac{\dot{b}}{\sigma}$ & 岸 & & {$[0$} & & 管 $\mathrm{E}$ \\
\hline & ++ & + & + & ++ & + & + & ++ & + & + & ++ & + & & ++ & + &.+ & + & + & $+1+$ & + & + & $\overrightarrow{8}$ \\
\hline & ++ & + & + & ++ & + & + & ++ & + & + & ++ & + & & ++ & + & + & +1. & + & ++ & & + & 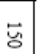 \\
\hline & ++ & + & & ++ & + & + & ++ & + & $\theta_{+}$ & ++ & + & &.+ & + &.+ &.+ & . & ++ & & + & $\tilde{8}$ \\
\hline t & ++ & + & & ++ & + & + & ++ & + & + & ++ & + & + &.+ & + &.+ &.+ &. & ++ & & + & 误 \\
\hline+ & ++ & + & + & ++ & + & + & ++ & + & + & ++ & . & + &.+ &. & + & +1. & . & ++ & + & + & 岁 \\
\hline+ & ++ & + & + &.+ & 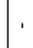 & + & ++ & + & + & ++ & . & t &.+ &. & +1 & +1. & . & ++ & 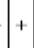 & + & 岁 \\
\hline+ & ++ & + & + &.+ & '. & + & ++ & + & . &.+ & . & 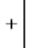 & . &. &. & +1. &. & ++ & & + & ১ \\
\hline+ & ++ & + & + & .1. & . & + &.+ & + & . &.+ & . & 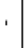 &. & . & . & & . & ++ & & + & 岕 \\
\hline+ & ++ & + & + & . & . & + & + & . & . &. & . & 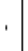 & . & . &. & t & . & ++ & & + & 岁 \\
\hline+ & ++ & + & + & ' & , & & . + + & . & . &. & . & & . & . & .1. &. & . & ++ & & 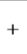 & $\ddot{山}$ \\
\hline+ & ++ & + & & . & ، & &. & . &. &. & ] & & . &. & .1. & ' & . & ++ & & + & 8 \\
\hline & + & . & . & . & . & & . & . & . &. & . & & . & '. & .1. & 1 & . & ++ & - & + & : \\
\hline & + & . & 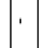 & . & , & & .1. & . & . & . & . & & . & . & .1. &. &. & ++ & & ' & ఃे \\
\hline & + & . & . & . & 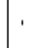 & & .1. & . & . &. & . & & . & . & .1. &. & . & ++ & & , & $\overrightarrow{8}$ \\
\hline & ' & . &. & . & . & & .1. & . & . &. & . & & . & . & .1. & . & . & ++ & & ' & $\stackrel{\circ}{8}$ \\
\hline & ' & 1. & ] & ' & . & &. & . & . & .1. & . & & . & . &. & 1 & . & ++ & & ' & $\stackrel{\circ}{\circ}$ \\
\hline & ' & . & . & . & 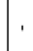 & & .1. & ' & . & ' & . & & . & . &. & . &. & +1. & & & 8 \\
\hline & & & . & & & & 1.1. &. & ' & . & ' & & . & 7 & 10 & . &. & +1. & & & 逭 \\
\hline & & & . & & & & & ' & &. & . & & ' & . &. & . & . &.+ & & & $\vec{\circ}$ \\
\hline & & & & & & & & ' & & & . & & . & . & . & . & . &.+ & & & 总 \\
\hline & & & & & & & & & & & & & & & & & . & & & & $\overrightarrow{8}$ \\
\hline
\end{tabular}

In order to prepare aldehyde (5), the acetal moiety was cleaved under acidic condition [18] (65\% acetic acid) for compound (3) to give (4) and oxidation of the product with sodium periodate to result (5), which gave a positive Tolen's test by formation a silver mirror [19]. The FTIR spectra for compound (4) and (5) were confirmed the formation of compound (5) by disappearance of the bands for $(\mathrm{O}-\mathrm{H})$ of compound (4) and exhibited the band at (1749) $\mathrm{cm}^{-1}$ for
$(\mathrm{C}=\mathrm{O})$ in compound (5) spectrum. The structure of (5) was confirmed by ${ }^{1} \mathrm{HNMR}$ which exhibited a signal at $\delta(12.5)$ ppm for $(\mathrm{CHO})$ and was characterized by ${ }^{13} \mathrm{CNMR}$ and (U.V-Vis) spectrum which showed one peak at (300) $\mathrm{nm}$ $\left(33333 \mathrm{~cm}^{-1}\right)$ assigned to $\left(\pi \longrightarrow \pi^{*}\right)$ and $\left(\mathrm{n} \longrightarrow \pi^{*}\right)$ transitions. Finally, the mass spectrum showed a highest mass signal at $[\mathrm{M}+1]=413$ with signal intensity $100 \%$.

The FTIR spectrum for compound (6) confirm the formation of the polyacetal by disappearance of the band (1749) $\mathrm{cm}^{-1}$ for $\left(\mathrm{C}=\mathrm{O}_{\text {ald }}\right)$ and the appearance of the band $(1279-1068) \mathrm{cm}^{-1}$ for $\left(-\mathrm{C}-\mathrm{O}-\mathrm{C}_{\text {ace. }}\right)$.

\section{B. Antimicrobial Studies}

Antimicrobial activity of the synthesized compound and their corresponding metal complexes was determined against two Gram-negative bacterial strains (Escherichia coli and KlebsiellaPneumoniae), two Gram-positive bacterial strains (Staphylococcus aureus andStaphylococcus Albus) and two fungal (Aspergillusniger and Yeast) Tables I and II respectively.

The synthesized polycyclicacetal and all polymer complexes exhibited a good degree of inhibitory effects on the growth of different bacteria and fungi isolates. Antibacterial agents may affect cells in a variety of ways, many of which are poorly understood [20]. Most of the commonly used antibacterial chemotherapeutic agents act by one of the following basic mechanisms: competitive antagonism of some metabolite, inhibition of bacterial cell wall synthesis, action on cell membranes, inhibition of protein synthesis, or inhibition of nucleic acid synthesis [21].

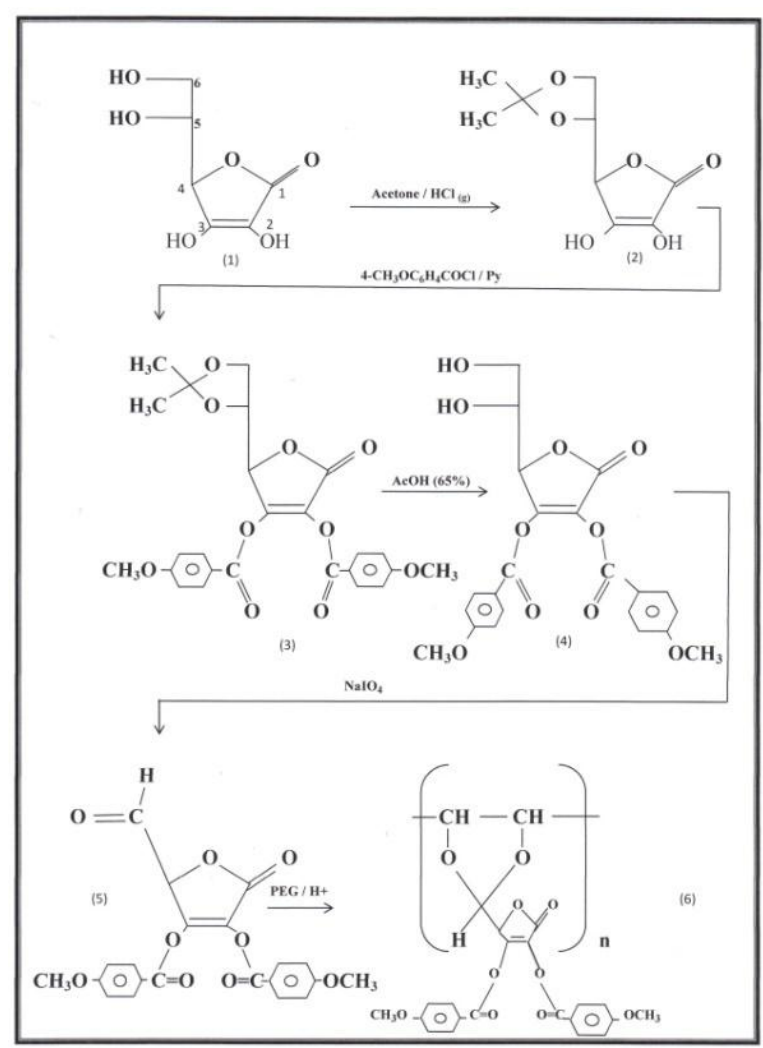

Scheme 1 . The scheme of prepared polycyclicacetal.

The Polymer metal complexes showed higher activity than the free polymer, this may be due to, when the metalcomplex chelate is formed, it will has the ability to dissolve in the bacterial membrane lipid, thus facilities the 
penetration of drug through the bacterial cell wall and became more efficient against bacteria, in the other side the presence of some compound in the microbial agent which have some groups like $\left(-\mathrm{SH},-\mathrm{NH}_{2},-\mathrm{COOH},-\mathrm{OH}\right)$ that attracts the metal elements $(\mathrm{Cu}, \mathrm{Co}, \mathrm{Ni}, \mathrm{Mn}, \mathrm{Hg}, \mathrm{Ag})$ to form specific chelate complexes and thus it will increase the lipophilicity of the complexes which in turn will facilitate concentration in the bacterial cell, where the eventual action is to impair their ability to synthesis protein on the ribosomes.

The fungi were found to be completely resistant to the polymeric preparation in this research irrespective of the fact that it was successful as antibacterial agents. It has been found that prepared metal polymeric complex compounds give better result when used as antifungal drugs, but in undesirable level to be considered as antifungal.

TABLE II: ANTIBACTERIAL ACTIVITy OF THE POLyACETAL AND ITS METAL COMPLEXes (Minimum INHIBITORY CONCENTRATION)

\begin{tabular}{|c|c|c|c|c|c|c|c|c|c|c|c|}
\hline \multirow{2}{*}{ Metal } & \multirow{2}{*}{ Isolates } & \multicolumn{10}{|c|}{ Concentration $\mu \mathrm{g} / \mathrm{ml}$} \\
\hline & & 900 & 950 & 1000 & 1050 & 1100 & 1150 & 1200 & 1250 & 1300 & 1350 \\
\hline \multirow{2}{*}{$\begin{array}{c}\text { PEG-Cyclic } \\
\text { Acetal }\end{array}$} & Aspergillusniger & + & + & + & + & + & + & + & + & - & - \\
\hline & Yeast & + & + & + & + & + & + & + & + & + & - \\
\hline \multirow{2}{*}{ With-Ag } & Aspergillusniger & + & - & - & - & - & - & - & - & - & - \\
\hline & Yeast & + & + & - & - & - & - & - & - & - & - \\
\hline \multirow{2}{*}{ With-Hg } & Aspergillusniger & + & + & + & + & - & - & - & - & - & - \\
\hline & Yeast & + & + & + & + & + & + & - & - & - & - \\
\hline \multirow{2}{*}{ With-Cu } & Aspergillusniger & + & + & - & - & - & - & - & - & - & - \\
\hline & Yeast & + & + & + & + & + & + & - & - & - & - \\
\hline \multirow{2}{*}{ With-Ni } & Aspergillusniger & + & + & + & + & + & + & - & - & - & - \\
\hline & Yeast & + & + & + & + & + & + & - & - & - & - \\
\hline \multirow{2}{*}{ With-Co } & Aspergillusniger & + & + & + & + & + & + & - & - & - & - \\
\hline & Yeast & + & + & + & + & + & + & - & - & - & - \\
\hline \multirow{2}{*}{ With-Mn } & Aspergillusniger & + & + & + & + & + & + & - & - & - & - \\
\hline & Yeast & + & + & + & + & + & + & + & + & + & - \\
\hline
\end{tabular}

\section{REFERENCES}

[1] S. D. El-RefaieKenawy, Worley, and R. Broughton, "The chemistry and applications of antimicrobial polymers: A state-of-the-art review," Biomacromolecules, vol. 8, no. 5, pp. 1359-1384, 2007.

[2] A. Benhhira and E. Franta, Francois J. Macromolecules, vol. 25, pp. 5697-5704, 1992.

[3] A. Matsushima, H. Nishimura, Y. Ashihara, Y. Yokota, and Y. Inada, "Modification of E.Coli Aspariginase with 2, 4-Bis (methoxypolyethyleneglycol)-6-chloro-striazine (activated PEG2); Disappearance of binding ability towards anti-serum and retention of enzymatic activity," Chem. Lett., pp. 773-776, 1980.

[4] Y. Ashihara, T. Kono, S. Yamazaki, and Y. Inada, "Modification of E. coli L-asparaginase with polyethylene glycol: disappearance of binding ability to anti-asparaginase serum," Biochem Biophys Res Commun, vol. 83, pp. 385-391, 1978.

[5] A. Abuchowski, T. van Es, N. Palczuk, and F. Davis, "Alteration of immunological properties of bovine serum albumin by covalent attachment of polyethyleneglycol," J. Biol. Chem., vol. 252, p. 3578, 1977.

[6] P. Lisi, T. van Es, A. Abuchowski, N. Palczuk, and F. Davis, "Enzyme therapy. I. Polyethyleneglycol: $\beta$-glucuronidase conjugates as potential therapeutics agents in acid mucopolysaccharidosis," $J$. Appl. Biochem, vol. 4, no. 19, 1982.

[7] L. J. Machlin, Handbook of Vitamins, $2^{\text {nd }}$ ed., 1991, Marcel Dekker, Inc.

[8] A. Bossi, S. A. Piletsky, E. V. Piletska, P. G. Rightti, A. Turner, and P. F. Anthony, "An assay for ascorbic acid based on polyanilinecoated microplates," Anal Chem., vol.72, p. 4296, 2000.

[9] I. Yamamoto, A. Tai, Y. Fujinami, K. Sasaki, and S. Okazaki, "Synthesis and characterization of a series of novel monoacylated ascorbic acid derivatives, 6-O-acyl-2-O-alpha-D-glucopyranosyl-Lascorbic acids, as skin antioxidants," J. Med. Chem., vol. 45, p. 462, 2002.

[10] L. L. Salomon, "Preparation of 5, 6-o-isopropylidene-L-ascorbic acid," Experientia, vol.19, no. 12, pp. 619-620, 1963.

[11] H. Dudley and I. Fleming, Spectroscopic Methods in Organic Chemistry, $5^{\text {th }}$ ed., McGraw-Hill companies, London, 1995, p. 24.

[12] A-J. A. Mukhlis, M. S. AL-Rawi, J. H. Tomma, and A. H. Al-Dujaili, "Synthesis and characterization of new oxazepines derived from derythroascorbic acid," Ibn Al-Haitham J. for Pure \& Appl. Sci., vol. 25, no. 2, pp. 293-307, 2012.

[13] M. A. Younus, "Synthesis and characterization of polycyclicacetal derived from PEG \&Erythro-ascorbic acid derivative and study its effect on the activity of ACh Enzyme (In Vitro)," Chemical and Process Engineering Research, vol. 10, pp. 33-38, 2013.

[14] T. M. Salih, R. M. Rumez, M. A. Younus, B. I. Khalil, and B. W. Khammas, "Synthesis, characterization, and anti-microbial study of metal complexes of polycyclicacetal derived from PVA \& erythroascorbic acid derivative," J. of Life and Technologies, vol. 1, no. 1, pp. 51-55, 2013.

[15] F. A. Carey, Organic Chemistry, $6^{\text {th }}$ ed., the McGraw-Hill Companies, Inc., New York, 2006, p. 767.

[16] C. Julio, "Antimicrobial susceptibility of Streptococcus pneumoniae: serotype distribution of penicillin-resistant strains in Spain," Antimicrobial Agents and Chemotheraby, Ang, vol. 22, pp. 222-225, 1982.

[17] J. G. Collee., A. G. Fraser, B. P. Marmio, and A. Simmons, Practical Microbiology, $4^{\text {th }}$ ed., Church Hill Livingstone, New York, 1999, p 118.

[18] T. Gazivoda, K. Wittine, I. Lovric, D. Makuc, J. Plavec, M. Cetina, D. Mrvos-Sermek, L. Suman, M. Kralj, K. Pavelic, M. Mintas, and S. Raic-Malic "Synthesis, structural studies, and cytostatic evaluation of 5,6-di-O-modified L-ascorbic acid derivatives," Carbohydr. Res., vol. 341 , no. 4, pp. 433-442, 2006

[19] A. I. Vogel, Vogel's Textbook of Practical Organic Chemistry, $5^{\text {th }}$ Ed., John Wiley and Sons, Inc., New York, 1989, p. 1219.

[20] K. J. Known-Chung and J. E. Burnt, Medical Microbiology, Lea and Fegbiger, 1992, p. 82.

[21] A. Goth, Medical Pharmacology Principles and Concepts, $10^{\text {th }}$ ed., 1981 , p. 615.

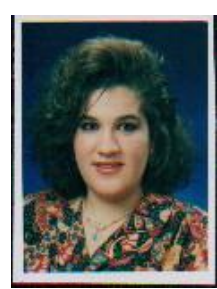

Maha A. Younus was born in Baghdad, Iraq on February 1, 1974. She received her B.S. degree in chemistry in 1995, MSc degree in physical chemistry in 1998, and $\mathrm{PhD}$ degree in organic chemistry - biopolymers in 2003 from the College of Education, Ibn Al-Haitham in Baghdad University, Baghdad, Iraq.

She is an assistant professor who worked as a lecturer since 1998 in Baghdad University, College of Education-Ibn Al-Haitham, Chemistry Department, Baghdad, Iraq. Her research interests include the synthesis and development of polymers biopolymers, controlled drug release, hydrogel and antimicrobial studies.

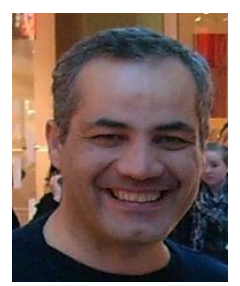

Khalil Bassam Ibrahim was born on July 25, 1969 in Baghdad, Iraq. His nationality is Swedish. He received his BSc degree from Department of Chemistry, College of Education, University of Mosul, Iraq in 1991. He got his MSc degree in polymer science \& technology, Department of Chemistry, College of Education, University of Basrah, Iraq, in May 1995. He received his $\mathrm{PhD}$ degree in biopolymers \& controlled drug release, from Department of Chemistry, College of Education, University of Baghdad, Iraq in August 2003. He worked as a manager assistant in 
Saddam Centre for Pharmaceutical and Scientific Research, Baghdad, Iraq from July 2001 to April 2003. And he has been working as a lecturer in University of Baghdad, College of Education, Ibn Al-Haitham, Department of Chemistry, Baghdad, Iraq since September 1997. He is also a clinical investigator in Jenin Private Hospital, Baghdad, Iraq since January 1997.

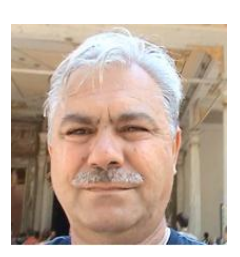

Taha M. Saleh was born in Baghdad, Iraq on March 7, 1957. He received his BSc. degree in chemical engineering from College of Engineering, Baghdad University, Baghdad, Iraq in 1979 and both MSc. in 1997 and $\mathrm{PhD}$. degrees in 2002 in organic chemistry - polymer technology from College of Education, Ibn Al-Haitham, Baghdad University, Baghdad, Iraq. He worked in research fields within a team work in consultant center in Baghdad as a chemical engineer from 1979 to 2002. He joined the college of basic education, university of Al-Mustansyria as a stuff teaching member (lecturer) since 2002 as an assistant professor. His research interests include synthesis and development of polymer for applications in rubber and polymer technology and organic chemistry.

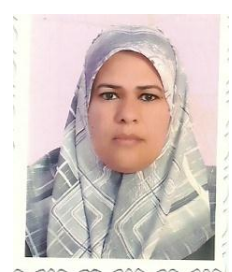

Rasmia M. Rumez was born in Baghdad, Iraq on December 10, 1970. She received her B.S. degree in chemistry in 1992, MSc degree in organic chemistry in 1998 , and $\mathrm{PhD}$ degree in organic chemistry in 2011 from the College of Education, Ibn AlHaitham, Baghdad University, Baghdad, Iraq. She worked as assistant chemist from 1992 to 1998 and a lecturer since 1998 in Baghdad University, College of Education, Ibn Al-Haitham, Chemistry Department, Baghdad, Iraq. Her research interests include organic chemistry, synthesis, carbohydrates, antimicrobial and enzymic studies. 